\title{
SOSIO-RELIGIUS PESANTREN: AKTUALISASI NILAI-NILAI AGAMA DALAM RUANG SOSIAL KEMASYARAKATAN DI LOMBOK TIMUR
}

\author{
Muhammad War'i ${ }^{1}$ \\ ${ }^{I}$ Sekolah Tinggi Ilmu Tarbiyah (STIT) Darussalimin Nahdlatul Wathan Praya, Lombok \\ *CORRESPONDENCE: $\square$ akmaly.warok@gmail.com
}

\begin{abstract}
This paper discusses the socio-religious attitude of the pesantren which is manifested by the Islamic Boarding School Ma'had Darul Quran wal Hadith Al-Majidiyah As-Syafi'iyah Nahdlatul Wathan in a social context. Through the phenomenology approach, this research will elaborate on this. Islamic boarding schools are often represented by santri learning places with strict pesantren regulations. The santri stayed in certain locations (dormitories) with 24-hour caregiver supervision. This fact often leaves "empty spaces" in the form of "gaps" that occur between pesantren and society in general. Therefore a pesantren management model is needed which emphasizes the process of social interaction in its existence. The conclusion of this paper is the socio-religious attitude of the pesantren which is manifested in the form of intense social interaction between santri and society. This is because santri lodgings are scattered throughout the community houses in Pancor Village which is the location of the Islamic boarding schools. These socio-religious attitudes can be seen from the concern of santri to the community in helping people around to study the religious sciences and help them in matters of daily living.
\end{abstract}

\section{Abstrak}

Tulisan ini membicarakan sikap sosio-religius pesantren yang termanifestasikan dalam orientasi Pesantren Ma'had Darul Quran wal Hadits Al-Majidiyah As-Syafi'iyah Nahdlatul Wathan dalam konteks sosial kemasyarakatan. Melalui pendekatan fenomenologi, penelitian ini mengelaborasi hal tersebut. Pesantren sering kali direpresentasikan dengan tempat belajar santri yang cenderung ketat secara pemondokan. Diinapkan di lokasi tertentu (asrama) dengan pengawasan pengasuh selama 24 jam. Kenyataan tersebut sering kali meninggalkan ruang kosong berupa "gap" yang terjadi antara pesantren dan masyarakat secara umum. Oleh karena itu dibutuhkan model pengelolaan pesantren yang memuat bahkan menekankan proses interaksi sosial dalam eksistensinya. Kesimpulan yang diperoleh dari penelitian ini adalah sikap sosio-religius pesantren yang termanifestasi dari bentuk interaksi sosial yang intens antara santri dan masyarakat. Hal ini disebabkan karena pemondokan santri disebar di seluruh rumah masyarakat di Kelurahan Pancor yang merupakan lokasi pondok pesantren. Sikap sosioreligius tersebut tampak dari kepedulian santri kepada masyarakat dalam membantu masyarakat sekitar mempelajari ilmu-ilmu agama serta membantu mereka dalam urusan hidup sehari-hari.

\section{A. Pendahuluan}

Pesantren merupakan lembaga pendidikan yang menekankan pada hubungan intens antara kiai dan santri. Biasanya peserta didik di pondok pesantren dipondokkan di tempat khusus (asrama), sehingga diharapkan dari model ini adalah proses pendidikan yang berlangsung $24 \mathrm{jam}$. Oleh 
karena itu, pondok pesantren biasanya berada di komplek tertentu dengan pengawasan yang ketat dari para pembimbing asrama. Model pengelolaan pondok pesantren seperti ini menjadi bentuk umum pondok pesantren. Namun demikian, ada "ruang kosong" yang ditinggalkan oleh pola pengelolaan pondok seperti ini, yaitu adanya batas ( $\mathrm{gap}$ ) antara pesantren dan masyarakat umum. ${ }^{1}$

Gap tersebut pada gilirannya menuai konsekuensi tersendiri baik bagi pondok pesantren maupun masyarakat di sekitar pondok pesantren. Bagi pondok pesantren, gap tersebut bisa memicu konflik horizontal antara pengelola pesantren dan masyarakat sekitar. Di samping itu, menciderai peran pondok pesantren sendiri yang seharusnya menjadi agen perubahan untuk komunitas masyarakat secara umum. Sebagai lembaga sosial keagamaan, pesantren dengan kiainya mau tidak mau harus berhadapan dengan peran penting ini khususnya dalam perbaikan karakter masyarakat.

Sungguhpun eksistensi pondok pesantren teramat mengakar sebagai agen perubahan, namun dewasa ini orientasi pesantren juga berhadapan dengan arus deras kapitalisme. Banyak kemudian pesantren terlahir kembali dengan model-model yang luar biasa mewah dengan menawarkan ide-ide pembaharuan yang menjanjikan. Namun demikian inovasi pesantren yang cenderung menitikberatkan aspek sarana-prasarana dan pemikiran secara ilmu pengetahuan semata, membawa terhadap keringnya nilai-nilai spiritualitas tradisional yang sejatinya merupakan ruh dari pesantren itu sendiri.

Parahnya, model pesantren yang cenderung ekslusif secara bangunannya, juga seringkali ekslusif dalam pemikiran. Akhirnya, pesantren sering kali menjelma sebagai bangunan mewah di tengah pemukiman masyarakat umum. Keberadaannya seperti menara gading yang tak terjangkau masyarakat sekitar. Terpotong dari dunia sosial dan menjadi independen dengan modelnya sendiri, sehingga peran sosial pesantren menjadi luntur. Kegelisahan semacam ini juga pernah dikemukakan oleh Profesor Nadirsyah Hosen. Dalam pengantarnya pada sebuah buku berjudul Peradaban Sarung, dia mencoba menyinggung model pesantren yang dewasa ini banyak terjebak justru dalam praktik yang hanya berbau eksistensi semata dan melupakan nilai-nilai esensial di dalamnya. Amaliah pesantren seperti kharisma kiai, hubungan sosiologis antara pesantren dan masyarakat sekitar, serta berbagai aspek-aspek sosio-spiritual banyak yang hilang pada diri pesantren masa kini. $^{2}$

Dengan beranjak dari beberapa pertimbangan di atas, maka upaya mengkaji pola pengembangan pesantren yang berbasis kemasyarakatan dipandang perlu diangkat dalam kajian ilmiah untuk memberikan warna pada model-model pengelolaan pesantren. Harapan penulis, kajian ini mampu memberikan gambaran tentang hubungan pesantren dengan sosialnya, sehingga mampu menjadi inspirasi dalam pengelolaan Pondok Pesantren.

Memang apa yang dikemukakan pada pendahuluan tulisan ini tidaklah mengeneralisir bahwa kenyataan pesantren dewasa ini semuanya sebagaimana yang disebutkan di atas, ada banyak pondok pesantren yang mungkin masih memegang prinsip sosio-religiusnya sehingga relasi pesantren dengan masyarakat sekitar masih tetap terjalin. Umumnya pola interaksi antara pesantren dan masyarakat sekitar dapat dilihat pada majelis ta'lim yang diadakan oleh pesantren, khusus untuk masyarakat sekitar. Biasanya kegiatan tersebut berlangsung sekali dalam seminggu. Hal ini merupakan pola umum model relasi pesantren dan masyarakat sekitar.

${ }^{1}$ Ronald Lukens-Bull, "MADRASA BY ANY OTHER NAME: Pondok, Pesantren, and Islamic Schools in Indonesia and Larger Southeast Asian Region," JOURNAL OF INDONESIAN ISLAM 4, no. 1 (June 1, 2010): 1-21-21, https://doi.org/10.15642/JIIS.2010.4.1.1-21.

${ }^{2}$ Ach Dhofir Zuhry, Peradaban Sarung: Veni, Vidi, Santri (Jakarta: PT Elex Media Komputindo, 2018), viii. 
Kajian tentang pesantren lebih banyak berbicara pada sejarah dan model pendidikan yang dijalankan. Herman DM misalnya, mengangkat tentang sejarah pesantren di Indonesia. ${ }^{3}$ Di sisi lain, Suryawan meneliti tentang pola pendidikan yang dikembangkan pada salah satu pesantren di Jawa Barat. ${ }^{4}$ Sejalan dengan itu, Asmad Hamisy dan Abdul Tolib memaparkan tentang berbagai pola manajemen pondok pesantren ${ }^{5}$ dan model pendidikan pesantren modern. ${ }^{6}$ Kemudian ada juga tulisan dengan pendekatan filosofis tentang pesantren yaitu tulisan Muhammad Munadi yang mengkaji tentang integrasi keilmuan pada pendidikan pesantren. ${ }^{7}$ Selain itu, tulisan I'anatut Thoifah tentang model Pesantren Rakyat Al-Amin yang berada di Kabupaten Malang. Penelitian mengungkap model orientasi Pesantren, di mana masyarakat dijadikan sebagai santri pesantren. ${ }^{8}$ Demikian pula berbagai kajian tentang pesantren yang sangat banyak. Namun demikian, sebagaimana yang peneliti singgung sebelumnya, kajian-kajian tersebut lebih berbicara pada sejarah dan pola pendidikannya.

Untuk Pesantren Rakyat Al-Amin di atas, menurut peneliti unik secara pola relasi sosiologisnya. Pesantren yang dipimpin oleh Kiai Abdullah Sam itu menjadikan masyarakat sekitarnya langsung sebagai santrinya. Artinya santri asuhannya melingkupi semua masyarakat di sekitar pondok pesantren. Seperti namanya, pesantren tersebut benar-benar mengorientasikan eksistensinya terkait dengan keberadaan rakyat. Patologi-patologi yang sifatnya sosiologis menjadi titik perhatian pesantren tersebut, seperti: kemiskinan, kebiasaan amoral masyarakat, minuman keras, narkoba yang marak terjadi di masyarakat sekitar pondok pesantren. ${ }^{9}$ Namun demikian, pesantren tersebut tidak menunjukkan pola interaksi yang timbal balik. Posisi pesantren lebih sebagai sentrum perubahan untuk setiap persoalan sosial kemasyarakatan.

Adapun tulisan ini lebih melihat pada pola relasi pesantren dengan sosialnya. Objek penelitian adalah pesantren yang menempatkan santri-santriwatinya justru di rumah-rumah masyarakat dan tidak membuat asramanya sendiri secara khusus. Pesantren tersebut berada di Kelurahan Pancor Kota Selong Kabupaten Lombok Timur yang bernama Ma'had Darul Quran wal Hadits alMajidiyah as-Syafi'iyah Nahdlatul Wathan (MDQH-NW). Pondok pesantren tersebut telah berusia sekitar 52 tahun. Selama itu ia tetap konsisten dalam jalur sosial keagamaannya.

Selain orientasi sosiologisnya, ketertarikan peneliti terhadap fenomena ini juga karena peneliti pernah menjadi bagian dari santri pondok pesantren tersebut. Penulis merasakan dampak sosioreligius yang mengagumkan dari pola eksistensi pondok pesantren semacam ini. Meski membiarkan santri-santriwatinya tinggal bersama masyarakat, tetapi tanggung jawab moral berupa pendidikan

\footnotetext{
${ }^{3}$ Herman Herman, "SEJARAH PESANTREN DI INDONESIA,” Al-TA'DIB 6, no. 2 (July 1, 2013): 145, https://doi.org/10.31332/atdb.v6i2.311.

${ }^{4}$ Suryawan Suryawan, "Pola Pendidikan Akidah Di Pesantren Dalam Membentuk Karakter Santri (Studi Kasus Tentang Pendidikan Akidah Di Pondok Pesantren Nurussalam Cintaharja Kujang Cikoneng Ciamis Jawa Barat)" (UPI Bandung, 2013).

5"Pola-Pola Manajemen Pondok Pesantren | Al Qodiri : Jurnal Pendidikan, Sosial Dan Keagamaan," accessed June 8, 2019, http://ejournal.kopertais4.or.id/tapalkuda/index.php/qodiri/article/view/571.

${ }^{6}$ Abdul Tolib, "PENDIDIKAN DI PONDOK PESANTREN MODERN," Risâlah, Jurnal Pendidikan Dan Studi Islam 2, no. 1 (2015): 60-66.

7“'Integration of Islam and Science: Study of Two Science Pesantrens (Trensain) in Jombang and Sragen | Jurnal Pendidikan Islam,” accessed June $\quad 8, \quad 2019, \quad$ http://ejournal.uinsuka.ac.id/tarbiyah/index.php/JPI/article/view/1236.

${ }^{8}$ I'anatut Thoifah, "Model Pesantren Rakyat Al-Amin Di Sumber Pucung Kabupaten Malang” (UIN Maulana Malik Ibrahim, 2014).

9“Pesantren Rakyat - Merakyat, Bermartabat," accessed June 8, 2019, http://pesantrenrakyat.com/.
} 
agama dan spiritualitas tetap bisa berlangsung dengan maksimal. Oleh karena itu, peneliti melihat pola pendidikan pesantren yang dikembangkan oleh MDQH-NW sungguh menarik untuk dikaji.

Ada beberapa manfaat penelitian yang bisa disumbangkan oleh tulisan ini. Pertama secara teoritis, kajian berbasis pesantren ini akan memperkaya keterangan-keterangan tentang pola pengembangan pondok pesantren yang ternyata banyak yang memiliki pola berbeda (unik) sehingga mampu memberikan warna pada kajian-kajian ilmiah kepesantrenan. Kedua secara aplikatif, kajian ini akan memberikan alternatif model pengembangan pondok pesantren yang berbasis relasi kemasyarakatan. Sehingga pesantren tidak melulu terkesan ekslusif dan anti sosial serta sebagai pencetak kaum 'menara gading' sebagaimana yang sebagian orang tuduhkan.

Berdasarkan keterangan di atas, penelitian ini mengangkat dua poin masalah yang dipaparkan. Pertama, bagaimana pola akomodasi ruang sosial pada model pemondokan santri di Ma'had Darul Quran wal Hadits Al-Majidiyah As-Syafi 'iyah Nahdlatul Wathan? Kedua, bagaimana pola interaksi sosial pondok pesantren Ma'had Darul Quran wal Hadits Al-Majidiyah As-Syafi'iyah Nahdlatul Wathan dengan masyarakat sekitar? dan bagaimana nilai sosio-religius pesantren yang terkonstruksi dalam orientasi pendidikan dan pemondokan pesantren. Oleh karena itu tulisan ini bertujuan untuk mengetahui sikap sosio-religius pesantren yang termanifestasi pada model pemondokan di pesantren Ma'had Darul Quran wal Hadits Al-Majidiyah As-Syafi'iyah Nahdlatul Wathan

\section{B. Metode Penelitian}

Tulisan ini merupakan hasil dari penelitian lapangan (field research) yang dilakukan dengan pendekatan kualitatif fenomenologis. Metode ini digunakan untuk melihat fenomena. Sebagaimana Husserls, Fenomenologi merupakan ilmu yang melihat fenomena kesadaran secara utuh. Fenomenologi merupakan ilmu yang berbicara tentang fenomena. ${ }^{10}$ Sejatinya, Fenomenologi berupaya untuk mengomunikasikan fenomena yang tampak dengan yang berada di baliknya berupa makna sesungguhnya dari fenomena tersebut. ${ }^{11}$ Tidak bisa dipungkiri bahwa Fenomenologi lahir dari rahim Filsafat kemudian berkembang dalam bidang-bidang keilmuan lainnya, seperti bidang Psikologi, Biologi (kesehatan), Sosiologi dan Bahasa. Adapun penerapan Fenomenologi dalam kajian sosial mulai digunakan pertama kali oleh Schutz. Dia menyebut bahwa Fenomenologi merupakan pisau analisis yang cocok untuk mengelaborasi fenomena sosial. Scutz terinspirasi dari beberapa pemikir sebelumnya seperti Weber dengan teori Fakta Sosial-nya dan Durkheim dengan teori Determinasi Sosial-nya. Selain itu struktur dalam teori Konstruksi Realitas Sosial (The Social Construction of Reality) yang dikemukakan oleh Peter Berger dan Luckmann juga memberikan Schutz inspirasi dalam mengembangkan Fenomenologi sebagai teori kajian sosial.

Secara teknis, Fenomenologi dalam kajian sosial dapat dituliskan sebagai berikut: pertama, fenomena dihadirkan dalam sebuah kesengajaan (intensionality) yang total sehingga benar-benar mengelaborasi sebuah fenomena baik yang tampak maupun tidak tampak. Kedua, fenomena dihadirkan dalam sebuah epoce yaitu konsep melepaskan pemahaman subjektif peneliti. Artinya data penelitian diberikan hadir sepenuhnya untuk menggambarkan dirinya, terlepas dari pemahaman sebelumnya yang dimiliki peneliti. ${ }^{12}$ Ini penting untuk mengarahkan pemahaman tentang fenomena secara objektif. Ketiga, intersubjektifitas, yaitu menghubungkan keterangan-

\footnotetext{
${ }^{10}$ Engkus Kuswarno, Fenomenologi: Metode Penelitian Komunikasi: Konsepsi, Pedoman, Dan Contoh Penelitiannya, Seri Metode Penelitian Komunikasi (Bandung: Widya Padjadjaran, 2009), 48.

${ }^{11}$ H. Ferguson, "Phenomenology and Social Theory," in Handbook of Social Theory, ed. G. Ritzter and B. Smart (London: Sage, 2001), 93, http://eprints.gla.ac.uk/33836/.

${ }^{12}$ Kuswarno, Fenomenologi.
} 
keterangan yang diberikan oleh informan tentang fenomena terkait. Setelah itu barulah dilakukan reduksi fenomenologi, yaitu menghadirkan data yang diperoleh dalam susunan bahasa.

Pendekatan fenomenologi terutama yang digunakan dalam kajian sosial lebih efektif digunakan untuk mengelaborasi masalah yang dihadirkan dalam penelitian ini. Harapan dari penggunaan pendekatan fenomenologi ini adalah untuk memberikan gambaran objektif tentang fenomena. Hal tersebut mengingat peneliti sebagai subjek yang pernah mondok di MDQH-NW, sehingga pengalaman subjektif peneliti bisa digunakan dalam melakukan intersubjektifitas dengan keterangan-keterangan dari informan yang baru.

Kaitannya dalam kajian ilmu sosial, metode dalam penelitian Fenomenologi dilakukan dengan melakukan langkah-langkah sebagai berikut: pertama, melakukan konsistensi logis, yaitu mengkonsep objek dalam suatu konsep ilmiah sehingga bisa dimaknai dengan baik. Kedua, interpretasi subjektif. Yaitu proses memahami tindakan-tindakan objek riset untuk dihadirkan dalam suatu konsep makna. Artinya tindakan objek sebagai informan dikonsepsikan dengan menghubungkannya dengan pandangan-pandangan informan lainnya. ${ }^{13}$ Model inilah yang dalam konsepnya Husserls disebut sebagai intrsubjektif (intersubjective). ${ }^{14}$ Selanjutnya, barulah dilakukan reduksi fenomenologis, yaitu peroses menyusun makna-makna atas sebuah fenomena dalam struktur kebahasaan. ${ }^{15}$

Dalam penelitian ini, digunakan istilah informan dan key informan untuk penggalian data. Informan adalah seorang yang dijadikan objek dalam penelitian ini. Yaitu para santri (thullab) yang sedang atau pernah menjadi santri di Pondok Pesantren Ma'had Darul Quran wal Hadits alMajidiyah As-Syafi'iyah Nahdlatul Wathan. Kemudian key informan adalah tenaga pendidik yang aktif serta beberapa orang dari masyarakat penyedia jasa pemondokan. Posisi key informan adalah subjek peneliti sehingga posisinya sejajar dengan peneliti. Hal ini penting untuk menghadirkan kajian penelitian ini dalam suatu kerangka riset yang utuh. Pengumpulan data dilakukan dengan beberapa cara yaitu: Wawancara mendalam (indeftinterview), Observasi dan Focus Group Discussion (FGD).

Adapun untuk analisis datanya, digunakan model analisis fenomenologi yang dikembangkan oleh Husserls yaitu: breacketing, yaitu proses mengkeranjangkan data untuk membebaskannya dari interpretasi subjektif peneliti. Kemudian data yang dikeranjangkan dilanjutkan ke tahap horizonalizing, yaitu proses menghubungkan antara satu dengan lain pendapat yang diperoleh dari informan-informan riset. Data yang didapat kemudian dihorizon sebagai esensialisasi dari proses sebelumnya. Barulah kemudian data yang diperoleh dikonstruksi dalam sebuah laporan tertulis. ${ }^{16}$

\section{Pembahasan}

\section{Profil Singkat Ma'had Darul Quran wal Hadits Al-Majidiyah As-Syafi'iyah}

Ma'had Darul Quran wal Hadits Al-Majidiyah As-Syafi'iyah Nahdlatul Wathan (MDQH-NW) merupakan salah satu lembaga non-formal yang bernaung dibawah Yayasan Pendidikan Hamzanwadi Darunnahdatain Nahdlatul Wathan. Pertama kali didirikan pada tahun 1965 oleh TGKH. Muhammad Zainuddin Abdul Majid. ${ }^{17}$ Dengan demikian, pesantren ini secara usia sudah

\footnotetext{
${ }^{13}$ Kuswarno, 38.

${ }^{14}$ Ferguson, "Phenomenology and Social Theory."

${ }^{15}$ Kuswarno, Fenomenologi, 38.

${ }^{16}$ Kuswarno, 38.

${ }^{17}$ Muslihan Habib, Visi Kebangsaan Religius Tuan Guru Kyai Haji Muhammad Zainuddin Abdul Majid
} (Jakarta: Bania Publishing, 2014). 
cukup matang. Model kurikulum yang dikembangkan tetap sebagaimana model kurikulum pesantren klasik yaitu model halaqoh. Hanya ada beberapa transformasi berupa ruang kelas dan meja duduk. Kitab-kitab yang digunakan juga masih seperti pesantren dahulu yaitu kitab-kitab klasik. $^{18}$

Letak berdirinya Pesantren ini tepatnya adalah di kampung Bermi, Kelurahan Pancor, Kecamatan Selong Kabupaten Lombok Timur. Di sekitar Pesantren ada tiga kampung yang bersebelahan, biasanya merupakan tempat para santri-santriwati mondok, yaitu: Sanggeng di sebelah Utara, Jorong di sebelah Barat, Lauk Masjid di sebelah Selatan.Sementara itu sebelah Timur adalah Kota Selong. Jarak antara kampung-kampung tersebut dengan Pesantren MDQH ratarata 500 meter.

MDQH-NW menjadi salah satu pesantren yang sangat dibanggakan masyarakat Lombok secara umum. Bagaimana tidak, hampir tidak ada alumni pesantren ini yang tidak digunakan di masyarakat, tentunya dalam hal praktik keagamaan, seperti menjadi takmir masjid ataupun mushalla. Itulah mengapa pesantren ini selalu kebanjiran santri setiap tahunnya, baik yang berasal dari Lombok sendiri ataupun Sumbawa. Bahkan ada pula santri yang datang dari Sulawesi dan Kalimantan.

Secara jenjang pendidikan, MDQH merupakan lembaga pendidikan setara perguruan tinggi. Dipimpin oleh seorang yang berstatus 'Amidul Ma'had yang kalau dalam lembaga formal berstatus Rektor. Waktu yang ditempuh untuk menyelesaikan pendidikan di MDQH juga sama dengan perguruan tinggi tingkat S1 yaitu empat tahun. Adapun gedung pendidikannya sebagaimana lembaga pendidikan formal pada umumnya. Terdapat satu gedung kuliah, sebuah musholla cukup besar tempat mengaji dengan metode halaqoh.

Untuk tenaga pendidik, para masayikh 'pengajar' sebagian besar merupakan alumnus Timur Tengah yang pernah menimba ilmu di As-Saulatiah Makkah, maupun Al-Azhar Kairo Mesir. Bukubuku yang digunakan semuanya merupakan kitab-kitab berbahasa Arab. Hingga saat ini ada ribuan santri yang mengaji di pesantren ini, baik laki-laki maupun perempuan. Uniknya, pesantren ini tidak membuat asrama khusus bagi santri-santriwatinya. Mereka dipersilahkan untuk mondok di rumahrumah masyarakat sekitar pondok pesantren yang terdapat di Kelurahan Pancor Kota Selong, Kabupaten Lombok Timur.

\section{Pesantren, Masyarakat dan Ruang Sosial}

Secara etimologis, pesantren berasal dari kata pe-shastra-an, di mana kata tersebut lebih akrab dengan istilah tradisi keagamaan Hindu di masa lalu. ${ }^{19}$ Kata yang kemudian dilafalkan 'Pesarean' memiliki medan makna tempat orang-orang menyendiri mengolah spiritualitas mereka. Pesantren biasanya menjadi tempat penanaman spiritual masyarakat yang cendrung kering karena aktifitas duniawi. Namun dalam arus sejarah, pesantren memiliki pola relasi yang dinamis dengan masyarakat. Pada masa kerajaan misalnya, pesantren memiliki hubungan spiritual dengan masyarakat berupa hubungan edukasi moral untuk membentengi diri dari gemerlap kehidupan dunia

${ }^{18}$ Raden Samidi and Suharno Suharno, "IMPLEMENTASI NILAI KEADILAN SOSIAL MELALUI PENDIDIKAN PERSPEKTIF TGKH ZAINUDDIN ABDUL MAJID," Fikri : Jurnal Kajian Agama, Sosial Dan Budaya, December 31, 2018, 374-84, https://doi.org/10.25217/jf.v3i2.314.

${ }^{19}$ Zuhry, Peradaban Sarung, 5. 
yang terlampau materialistis. ${ }^{20}$ Kemudian pada masa kolonialisme, relasi pesantren dan masyarakat bersifat kolaboratif dalam upaya melawan penjajah Belanda. ${ }^{21}$

Hubungan pesantren dan masyarakat mengalami pergantian orientasi pada masa orde baru, di mana pesantren yang biasanya berada di perkotaan berpindah kepada pelosok-pelosok desa karena intimidasi dari pemerintah pusat atas nama pembangunan. Banyak pesantren-pesantren yang digusur bangunannya dan menjadi pusat-pusat perbelanjaan. ${ }^{22}$ Dari beberapa keterangan tersebut, pesantren dan masyarakat menunjukkan hubungan yang positif. Namun demikian, sejarah tidak hanya mencatat hubungan pesantren dan masyarakat dalam hubungan yang senantiasa harmoni, tercatat pula beberapa pesantren yang justru melahirkan reaksi negatif dari masyarakat.

Kisah pesantren Lia Eden misalnya, awalnya memiliki hubungan yang harmonis dengan masyarakat, namun karena seiring waktu dianggap mengarah kepada pemahaman yang berbeda dan ekslusifitas golongan secara eksistensial, maka terjadilah penyerangan masyarakat sekitar pesantren terhadap pemondokannya. ${ }^{23}$ Ini menjadi catatan penting dalam arus relasi pesantren dan masyarakat. Dalam hal ini, Lia Eden tidaklah sendiri, pesantren-pesantren yang berorientasi pemahaman radikal juga banyak tumbuh subur di negeri ini yang secara aksiologis justru tidak menjadikan masyarakat tentram, bahkan membawa masyarakat menuju perpecahan dan keresahan.

Peneliti meyakini, adanya penyerangan masyarakat kepada pesantren-pesantren tertentu lebih disebabkan oleh sikap ekslusifitas yang berkembang di lingkungan pesantren, baik secara sengaja maupun tidak disengaja. Secara sengaja dalam arti pesantren tersebut dengan sadar mendirikan pondok pesantren untuk menumbuh-kembangkan ideologi tertentu yang bersifat radikal. Dan yang tidak sengaja seperti kesalahan cara pesantren dalam mengelola relasi sosial yang seharusnya dipupuk secara lebih baik lagi.

Selain pola relasi yang dinamis secara orientasi dan ideologi, pesantren masa kini banyak terjerumus dalam kubangan arus kapitalisme ${ }^{24}$, sehingga pesantren menjelma menjadi pasar. Tempat di mana orang-orang melakukan transaksi kebendaan semata. Adapun nilai spiritual yang seharusnya tidak boleh hilang dalam diri pesantren seolah tergadaikan dalam upaya membangun sarana dan prasarana pondok pesantren. Di tengah arus dinamika pesantren di atas, peneliti mencoba menghadirkan fenomena pemondokan di MDQH-NW sebagai salah satu model orientasi pesantren yang peka sosial, menyadari posisi sebagai agen perubahan. Juga sebagai pengingat bahwa pesantren masih akan menjadi sumber kesejukan bagi keringnya moralitas bangsa manusia belakangan ini.

Mengingat pola relasi yang dibangun dalam konteks penelitian ini adalah pola kesalingberhubungan, maka istilah yang digunakan adalah interaksi sosial. Mengacu Scutz, interaksi sosial lebih bersifat psiko-analisis, yang mana di dalamnya berlangsung proses saling mempengaruhi. Dalam hal ini, peneliti ingin mengungkapkan bahwa dalam fenomena ini berkembang hubungan yang tidak hanya transaksional materialistis antara santri dan masyarakat sebagai penyedia kos (pemondokan) tetapi lebih banyak berbau hubungan psikologis dan kesalingmengertian. Hal ini karena masyarakat juga banyak yang belajar ilmu agama dari santri

${ }^{20}$ Abdurrahman Wahid, Melawan Melalui Lelucon: Kumpulan Kolom Abdurrahman Wahid Di Tempo, Cet. 1 (Jakarta: Tempo, 2000), 21.

${ }^{21}$ Wahid, 41.

${ }^{22}$ Wahid, 42.

${ }^{23} \mathrm{Al}$ Makin Al Makin, Nabi-Nabi Nusantara: Kisah Lia Eden Dan Lainnya (Yogyakarta: UIN Suka Press, 2017), 38.

${ }^{24}$ Zuhry, Peradaban Sarung, viii. 
yang belajar di MDQH-NW. Dengan demikian, interaksi sosial yang dimaksud di sini sebagaimana konsep intekeraksi sosial Schutz adalah hubungan pesantren dan masyarakat yang berorientasi pada tiga hal yaitu: keitkutsertaan (inclution) kontrol (control) dan afeksi (afection). ${ }^{25}$

Adanya pola hubungan pesantren dan masyarakat ini kemudian penting untuk benar-benar dituang dalam ruang sosial kehidupan. Hal ini di samping sebagai bentuk tanggung jawab moral pesantren, juga sebagai bagian dari transformasi pendidikan masyarakat berbasis nilai agama. Adanya campur tangan pesantren dalam mengisi ruang sosial dengan nilai-nilai agama ini kemudian akan memberikan jalan terang perbaikan moral masyarakat dewasa ini yang mulai terkikis oleh arus deras kemajuan teknologi.

Konsep ruang sosial (social space) belakangan menjadi perhatian banyak peneliti sosial, karena dianggap seringkali dilupakan dalam suatu penelitian sosiologis. Ruang dimaknai sebagai tempat antara satu objek (individu atau group) dengan yang lainnya meleburkan tindakan-tindakan hidup yang berlangsung secara tidak sengaja. Sedangkan ruang sosial memiliki pemaknaan ruang di mana manusia sebagai mahluk sosial menjalani kehidupannya. Sebagai sebuah paradigma, ruang sosial dianggap sebagai pisau analisis yang cukup komprehensif terutama dalam konteks kajian komunikasi publik. Oleh karena itu, dalam konteks kajian ini, ruang sosial sebagaimana Christhin, merupakan pendekatan yang mengusung paradigma keterhubungan kelompok masyarakat berbasis tinjauan interktif (interactive perspective). ${ }^{26}$ Berdasar hal tersebut, penggunaan istilah ruang sosial dalam tulisan ini menunjuk pada keberlangsungan inteksi sosial antara santri pondok pesantren dengan masyarakat sekitar pondok sebagai penyedia layanan pemondokan.

\section{Interaksi Sosial pada Model Pemondokan di Pesantren MDQH-NW}

Sebagaimana yang pernah disinggung di muka, pemondokan di pesantren MDQH-NW tidak menggunakan model pemondokan santri pada umumnya yaitu menggunakan asrama (pondok), akan tetapi menggunakan rumah-rumah masyarakat di sekitar pesantren baik yang menyediakan lokal khusus di dekat rumahnya, ataupun yang langsung menempati salah satu kamar di rumah mereka. Konsekuensi dari pola pemondokan seperti ini adalah adanya hubungan yang sangat terbuka antara pesantren dan masyarakat sekitar.

TGH. Yusuf Makmun, sebagai Amidul Ma'had ketika ditanya tentang model pemondokan ini, memberikan jawaban, bahwa memang ada rencana untuk membuat asrama khusus untuk thullab Ma'had tetapi masih belum pasti kapan akan diwujudkan. Hingga saat ini belum ada lahan yang sudah dibebaskan untuk mengeksekusi wacana tersebut. Di samping itu, memang ada motif di balik pola pemondokan tersebut, santri dan santriwati (thullab dan tholibat) dipondokkan di luar bertujuan untuk melatih kepekaan sosial mereka. ${ }^{27}$

Di samping itu, dengan tinggalnya santri dan santriwati bersama masyarakat, itu akan memberikan dampak peningkatan ekonomi bagi masyarakat sekitar. Hal ini sejalan dengan prinsip yang diusung oleh Yayasan Pendidikan Hamzanwadi dalam Anggaran Rumah Tangga (ART)nya yaitu memberikan akses yang sebesar-besarnya untuk kesejahteraan masyarakat. ${ }^{28}$ Selain itu, pola pemondokan santri yang menggunakan jasa masyarakat sekitar juga memiliki tujuan dakwah

\footnotetext{
${ }^{25}$ Siti Mahmudah, Psikologi Sosial Sebuah Pengantar (Malang: UIN Press, 2010), 66.

${ }^{26}$ Christian Karrin Wolf, Social Space Analyses and The Socio-Spatial Paradigm in Social Work (Lunds: Socialhogskolan Lunds University, 2009), 5.

${ }^{27}$ TGH. Yusuf Makmun, Pengelolaan Pondok Pesantren, September 5, 2018.

${ }^{28}$ Yusuf Makmun.
} 
(perbaikan karakter sosial kemasyarakatan) sehingga ilmu yang didapat di pesantren bisa langsung diamalkan saat bergaul dengan masyarakat di pemondokan mereka.

Meskipun model pemondokan ini cendrung bersifat terbuka, akan tetapi para santri maupun santriwati tetap diikat dengan aturan-aturan pesantren, bahwa setiap santri harus tetap mengikuti kegiatan yang diadakan oleh pesantren. Adapun jadwal kegiatan santri sangatlah penuh, mulai dari pagi sekitar jam 07.00 sampai siang, kemudian dari sebelum ashar sampai pukul 21.00. Kegiatankegiatan tersebut berisi kajian-kajian keagamaan, ilmu alat (nahwu / sharaf) dan tentunya tafsir dan hadits. Sebagaimana namanya, pesantren ini menekankan pengajaran al-Quran dan al-Hadits.

Semua kegiatan tersebut diadakan di komplek pesantren Ma'had Darul Quran wal Hadits AlMajidiyah As-Syafi'iyah Nahdlatul Wathan. Akan tetapi, kegiatan santri tidak hanya selesai di sana. Dari pukul 22.00 sampai pukul 24.00 beberapa santri biasanya juga membuat jadwal diskusi di mushalla-mushalla milik masyarakat yang dibimbing oleh kakak tingkat mereka. Dengan demikian, pola pemondokan yang dikembangkan, meskipun bersifat terbuka di tengah-tengah masyarakat, tetapi tetap mengedepankan efektifitas belajar ala Pesantren.

Adapun mengenai output dari pola pemondokan ini sudah sangat jelas. Merupakan rahasia umum, bahwa setiap alumni MDQH-NW memiliki tempat tersendiri di hati masyarakat. Hampir tidak pernah ditemukan santri alumni pesantren ini yang menjadi sampah masyarakat. Rerata mereka mengambil posisi-posisi strategis di tengah masyarakat, terutama berkaitan dengan kegiatan-kegiatan keagamaan masyarakat. ${ }^{29}$ Ini membuktikan bahwa alumni pesantren ini memiliki kesalehan sosial yang tinggi.

Diterapkannya model pemondokan yang terbuka dengan masyarakat sekitar pesantren, menjadikan pesantren tersebut berada dalam interaksi sosial yang utuh dengan masyarakat sekitar. Sebagaimana kerangka konsep yang digunakan, maka pola interaksi sosial ini mengambil beberapa bentuk hubungan yaitu: keikutsertaan (inclution), kontrol (control), dan afeksi (afection).

Keikutsertaan di sini, dimaknai dengan keikutsertaan masyarakat dalam mengkonsumsi nilainilai keagamaan yang dipelajari oleh santri di pesantren mereka. Artinya, dengan tinggalnya para santri-santriwati di rumah-rumah masyarakat, membuat secara tidak langsung masyarakat ikut mengaji di pesantren. Dalam hal ini para santri berperan sebagai penyambung lidah pondok pesantren terhadap masyarakat sekitar pesantren dalam menginternalisasi nilai-nilai keagamaan.

Ibu Musti'ah misalnya, selaku masyarakat yang rumahnya ditempati oleh saya selaku santri di MDQH-NW, merasa mendapatkan pencerahan yang banyak tentang ilmu-ilmu keagamaan karena sering mendengar santri-santri berdiskusi di rumahnya, serta juga sering melontarkan pertanyaan kepada para santri yang tinggal di sana. Fenomena ini seolah menjadikan santri sebagai agen penyebar nilai-nilai yang diusung pesantren. Dalam pada itu, adanya pola interaksi semacam ini akan berdampak pada konstruksi sosial kemasyarakatan yang lebih madani.

Kenyataan di atas sejalan pula dengan prinsip dakwah yang dikembangkan oleh pendiri pesantren dahulu, yaitu TGKH. Muhammad Zainuddin Abdul Majid (w.1998). Pada masa kepemimpinannya Tuan Guru Pancor (sapaan akrabnya) membentuk salah satu program bidang dakwah dengan menempatkan santri-santrinya hidup berbaur bersama masyarakat guna menjadi juru dakwah di daerah-daerah yang dianggap masih belum tersentuh nilai-nilai keislaman. ${ }^{30}$ Dengan demikian penempatan santri-santriwati yang secara total berbaur dengan masyarakat memberi

\footnotetext{
${ }^{29}$ Ali Akbar Zubaidi, Pesantren Kemasyarakatan, September 10, 2018.

${ }^{30}$ Habib, Visi Kebangsaan Religius Tuan Guru Kyai Haji Muhammad Zainuddin Abdul Majid, 209.
} 
dampak positif, pertama bagi masyarakat sekitar dan yang selanjutnya bagi santri sendiri selaku persiapan menghadapi dunia kehidupan yang sebenarnya di daerah mereka masing-masing.

Pengalaman peneliti dengan bu Mustiah tersebut juga sama dengan yang dialami oleh santrisantri yang lain seperti Rizan Wadi Hamid, Asmaul Husna, Ahmad Zaini. Mereka juga merasakan hal yang sama terhadap keberadaan mereka di rumah ibu kos mereka. Kami sama-sama merasakan bahwa ada pengaruh yang signifikan terhadap pembangunan spiritualitas dan kesalehan sosial dengan berbaur bersama orang-orang baru seperti itu. ${ }^{31}$

Kemudian, yang kedua, bentuk interaksi sosial yang ada dalam fenomena ini adalah kontrol sosial. Dalam hal ini, kedua belah pihak sama-sama menjadi pengontrol dari satu sama lain. Masyarakat misalnya, menjadi pengontrol sikap para santri yang tinggal di rumah mereka. Tentunya sikap anak muda sering kali menunjukkan pada pemberontakan maupun perbuatanperbuatan tidak terpuji lainnya, tetapi dengan adanya masyarakat selaku ibu atau bapak kos mereka, menggantikan posisi orang tua mereka yang sebenarnya, membuat mereka merasa terawasi dan sungkan untuk berbuat sesuatu yang tidak dibenarkan secara moral.

Pola ini peneliti pikir sangat positif mengingat kelakuan banyak mahasiswa-mahasiswi belakangan yang melanggar batas-batas norma yang seharusnya tidak boleh dilewati. Posisi kontrol ini juga diamini oleh beberapa santri yang sempat peneliti temui. Mirjan Purbaya misalnya, karena jauh dari rumah (berasal dari KLU), dia sering kali membutuhkan pantauan orang lain untuk mengontrol gerak-gerik selama di pesantren $\mathrm{MDQH},{ }^{32}$ dan keberadaan 'orang tua' di pemondokannya menjawab hal tersebut. Demikian pula dengan Novi Astuti, seorang santriwati asal Bima, merasa sangat terkontrol dengan kehadiran "ibu asuh"nya selama berada di desa Sanggeng. ${ }^{33}$

Tidak hanya berbentuk kontrol yang sepihak, fenomena ini juga menggambarkan hubungan timbal balik dalam konteks kontrol-mengontrol. Pemilik rumah yang ditempati oleh santri atau santriwati merasa terpantau keamanan rumah mereka, juga merasa ada yang selalu mengingatkan mereka jika terjadi kesalahan atas sikap-sikap yang bertentangan dengan nilai-nilai keagamaan. Oleh sebab itu, hubungan pertalian antara pesantren dan masyarakat sangat membantu dalam membentuk tatanan kehidupan yang lebih baik dan harmoni.

Para santri juga selalu diingatkan untuk mengamalkan dan menyebarkan ilmu yang sudah didapatkannya. Kami dulu ingat pesan salah satu ustadz kami bahwa kehidupan bermasyarakat adalah kehidupan yang membutuhkan ilmu dan amal. Oleh karena itu, adanya interksi masyarakat dengan santri akan memicu adanya pengamalan ilmu para santri dalam memproses pengetahuan mereka. Meminjam Ach Dhofir Zuhry, santri bisa mendialogkan pengetahuan dengan kehidupan. ${ }^{34}$

Kontrol sosial yang dimainkan oleh santri ini, menjadi salah satu model suluk jamaah yang merupakan model suluk yang dijalani oleh guru besar pesantren, TGKH. Muhammad Zainuddin Abdul Majid. Bagi sang tuan guru, suluk tidak melulu dilakukan dalam suasana uzlah yang menuntut agar menghindar dari keramaian. Bahkan menurut beliau, suluk sambil berbaur dengan masyarakat jauh lebih utama, meskipun tentunya lebih sulit. ${ }^{35}$

Selanjutnya model interaksi sosial yang nampak dari fenomena ini adalah model afeksi. Interaksi sosial berupa afeksi ini merupakan konsekuensi logis dari suatu hubungan yang

\footnotetext{
${ }^{31}$ Hasil diskusi pada Focus Group Discussion (FGD), September 2, 2018.

${ }^{32}$ Mirjan Purbaya, Wawancara dengan salah seorang santri di MDQH, September 6, 2018.

${ }^{33}$ Novi Astuti, Wawancara dengan salah seorang santriwati di MDQH, September 6, 2018.

${ }^{34}$ Zuhry, Peradaban Sarung, 67.

${ }^{35}$ Muhammad War'i, Tirakat Sosial: Tasawuf Berparadigma Islam Nusantara (Yogyakarta: UAD Press,
} 2018), 51. 
berkesinambungan. Bagaimana tidak, selama empat tahun seorang santri tinggal bersama pemilik rumah, maka sudah barang tentu jika kasih-sayang di antara mereka bisa tumbuh. Peneliti sendiri, karena waktu yang lama hidup bersama, maka peneliti memanggil ibu kos dengan panggilan "ibu". Keberadaannya benar-benar seperti ibu sendiri. Hal ini terjadi karena kadang ibu kos yang punya rumah memilki kejiwaan yang cepat iba (respect), sehingga kalau lihat kami anak-anak yang tinggal di rumahnya belum makan, maka akan diberikan makanan.

Demikian pula yang dialami oleh beberapa santri MDQH yang peneliti temui. Musmuliadi misalnya, santri asal Sumbawa, selalu diperhatikan oleh ibu kosnya, "kasihan saya lihat kamu yang jauh dari orang tua." Demikian ibu kos sering mengatakan kepadanya. ${ }^{36}$ Memang hampir semua santri terutama dari luar pulau merasakan hal ini, karena intensitas mudik mereka cukup jarang. Hanya pada hari raya Idul Fitri mereka pulang kampung. Selebihnya, mereka tinggal di pemondokan. Itulah yang menyebabkan hubungan afektif tersebut terus berlangsung dalam orientasi program pesantren yang dijalani santri.

Selain itu, berbagai ritual keseharian, seperti bangun tidur, mandi, dan lain sebagainya, sering kali diingatkan oleh ibu pemilik rumah. Sehingga hampir proses afeksi tersebut tidak bisa dihindarkan. Bahkan sampai setelah menjadi alumni sekalipun, keinginan untuk tetap mengunjungi ibu pondok selalu tertanam di dalam diri. Kami para santri MDQH-NW selalu mengingat tentang orang-orang yang mengasihi kami di pemondokan tersebut. Itulah yang membuat interkasi sosial pesantren dengan masyarakat sekitar telah melahirkan suatu tatanan kehidupan yang harmoni.

Pola interaksi sosial pesantren dan masyarakat dalam fenomena ini dengan demikian mengarah kepada bentuk interaksi yang berimbang, di mana ada hubungan saling menguntungkan (simbiosis mutualisme). Masyarakat dengan adanya model pemondokan semacam ini mendapatkan beberapa keuntungan, seperti meningkatkan pendapatan bulanannya dari sewa pondok, kemudian bisa membuka usaha jual beli perlengkapan sehari-hari dan yang tidak kalah penting yaitu bisa belajar ilmu agama dari para santri yang tinggal di rumah mereka. Di sisi lain, pesantren juga mendapatkan keuntungan dengan tertunaikannya tanggung jawab moralnya sebagai agen perubahan dan pengabdi kepada masyarakat.

\section{Internalisasi Nilai-Nilai Agama dalam Ruang Sosial}

Setelah melihat pola interksi sosial yang terjalin antara pesantren dan masyarakat sekitarnya, dapat dikatakan bahwa pesantren melalui konsep pemondokannya yang berbasis sosial kemasyarakatan telah mendorong pada proses internalisasi nilai-nilai agama pada ruang sosial kemasyarakatan. Artinya pesantren yang sarat nilai-nilai agama telah memberikan kontribusi pada pembentukan karakter religius masyarakat karena hubungan intens antara masyarakat dan santri dalam kontek pemondokan mereka.

Keterisian ruang sosial dengan hal-hal yang positif merupakan hal yang layak dan penting untuk diapresiasi dan didorong untuk eksistensinya lebih jauh. Bagaimanapun pekerjaan rumah yang dewasa ini bergelayut dihadapan kita bersama adalah terjadinya berbagai polemik sosial kemasyarakatan seperti: kenakalan remaja, tawuran pemuda, dan berbagai masalah lain yang menuntut resolusi dengan segera. Keberadaan pesantren yang terbuka dalam aksesibilitas ruang seperti ini akan membantu dalam meresolusi persoalan tersebut. Ini mengingat peran pondok pesantren sebagai sentrum berkembang dan tersebarnya ilmu-ilmu keagamaan.

\footnotetext{
${ }^{36}$ Musmuliadi Musmuliadi, Pesantren Kemasyarakatan, September 7, 2018.
} 
Sungguhpun telah banyak panggung-panggung dakwah yang digagas oleh masyarakat untuk memberikan pencerahan kepada masyarakat, namun karena intensitas waktu yang terlampau sedikit, sehingga sangat berat untuk merevitalisasi nilai-nilai agama di tengah masyarakat luas hanya melalui mimbar pengajian. Dibutuhkan strategi yang lebih dari hanya sekedar penyampaian melalui pola dakwah lisan. Dalam dunia pesantren ada ungkapan yang cukup pamiliar: dakwah bil hal afdholu min dakwah bil lisan 'dakwah dengan tindakan lebih utama dari pada dakwah dengan tuturan' Dengan adanya pola pengembangan pesantren seperti di MDQH NW tersebut, memberikan langkah solutif dalam memperbaiki kualitas masyarakat. Melalui nilai-nilai agama yang dipegang santri dan kemudian tertularkan pada masyarakat umum melalui interaksi sosial, maka harapan untuk masyarakat yang lebih baik tidaklah sulit untuk diwujudkan.

Mengacu pada teori agency ala Giddens, bahwa konstruksi sosial tergantung pada agen-agen sosial yang berada di dalamnya. Ketika agen-agen sosial tersebut baik dan mampu memberikan peran terhadap kemajuan sosial, maka akan baik pula masyarakat secara umum. Demikian pula sebaliknya, ketika agen-agen sosial kehilangan taringnya dan tak mampu mengarahkan opini publik menuju nilai-nilai luhur, maka konstruksi sosial akan terancam. Oleh karena itu, santri sebagai aktor sosial yang sangat penting (dengan perangkat ilmu-ilmu keagamaannya), layak untuk diposisikan sebagai agen sosial, guna mewujudkan tatanan sosial yang damai dan penuh nilai.

Sosio-religius pesantren dengan demikian menggambarkan kepada bentuk tanggung jawab moral pesantren terhadap lingkungan masyarakat secara umum. Melalui pola pemondokan yang berbasis interaksi sosial, pesantren sebagai lembaga keagamaan akan mampu mengaktualisasi nilainilai agama dalam ruang sosial kemasyarakatan. Kenyataan ini pada gilirannya akan memberikan pola hubungan pesantren dan masyarakat yang berbasis simbiosis mutualisme, dimana pesantren menunaikan tanggung jawab moralnya dan masyarakat melaksanakan kewajiban moralnya. Pada akhirnya sikap sosio-religius tersebut akan menjadi sumbangan nilai yang sangat besar dalam khazanah kajian sosial keagamaan. Kita berharap pesantren-pesantren yang lain bisa menirukan hal ini untuk diterapkan dalam orientasi kepesantrenannya.

\section{Kesimpulan dan Saran}

Dari uraian di atas dapat disimpulkan bahwa model pemondokan yang dikembangkan oleh pesantren Ma'had Darul Quran wal Hadits Al-Majidiyah As-Syafi'iyah Nahdlatul Wathan berbasis pada interaksi sosial. Interkasi sosial yang terjalin antara Pesantren dan Masyarakat tersebut berbentuk tiga hal, yaitu: keikutsertaan masyarakat dalam visi-misi pesantren dalam konteks pendidikan, kontrol masyarakat atas santri (sebagai representasi pesantren) dan sebaliknya, serta adanya hubungan kasih sayang (afeksi) antara santri dan masyarakat yang rumahnya dijadikan pemondokan. Pola interaktif tersebut pada gilirannya melahirkan suatu sikap religius yang berpadu dengan kepedulian sosial. Dengan kata lain, pesantren sebagai lembaga keagamaan mampu mengaktualisasi nilai-nilai agama dalam ruang sosial kemasyarakatan secara umum.

\section{Daftar Pustaka}

Akbar Zubaidi, Ali. Pesantren Kemasyarakatan, September 10, 2018.

Al Makin, Al Makin. Nabi-Nabi Nusantara: Kisah Lia Eden Dan Lainnya. Yogyakarta: UIN Suka Press, 2017.

Astuti, Novi. Wawancara dengan salah seorang santriwati di MDQH, September 6, 2018. 
Ferguson, H. "Phenomenology and Social Theory." In Handbook of Social Theory, edited by G. Ritzter and B. Smart, 232-48. London: Sage, 2001. http://eprints.gla.ac.uk/33836/.

Habib, Muslihan. Visi Kebangsaan Religius Tuan Guru Kyai Haji Muhammad Zainuddin Abdul Majid. Jakarta: Bania Publishing, 2014.

Hasil diskusi pada Focus Group Discussion (FGD), September 2, 2018.

Herman, Herman. "SEJARAH PESANTREN DI INDONESIA." Al-TA'DIB 6, no. 2 (July 1, 2013): 145-58. https://doi.org/10.31332/atdb.v6i2.311.

"Integration of Islam and Science: Study of Two Science Pesantrens (Trensain) in Jombang and Sragen | Jurnal Pendidikan Islam.” Accessed June 8, 2019. http://ejournal.uinsuka.ac.id/tarbiyah/index.php/JPI/article/view/1236.

Karrin Wolf, Christian. Social Space Analyses and The Socio-Spatial Paradigm in Social Work. Lunds: Socialhogskolan Lunds University, 2009.

Kuswarno, Engkus. Fenomenologi: Metode Penelitian Komunikasi: Konsepsi, Pedoman, Dan Contoh Penelitiannya. Seri Metode Penelitian Komunikasi. Bandung: Widya Padjadjaran, 2009.

Lukens-Bull, Ronald. "MADRASA BY ANY OTHER NAME: Pondok, Pesantren, and Islamic Schools in Indonesia and Larger Southeast Asian Region." JOURNAL OF INDONESIAN ISLAM 4, no. 1 (June 1, 2010): 1-21-21. https://doi.org/10.15642/JIIS.2010.4.1.1-21.

Mahmudah, Siti. Psikologi Sosial Sebuah Pengantar. Malang: UIN Press, 2010.

Musmuliadi, Musmuliadi. Pesantren Kemasyarakatan, September 7, 2018.

"Pesantren Rakyat - Merakyat, Bermartabat." Accessed June 8, 2019. http://pesantrenrakyat.com/.

"Pola-Pola Manajemen Pondok Pesantren | Al Qodiri : Jurnal Pendidikan, Sosial Dan Keagamaan." Accessed June 8, 2019.

http://ejournal.kopertais4.or.id/tapalkuda/index.php/qodiri/article/view/571.

Purbaya, Mirjan. Wawancara dengan salah seorang santri di MDQH, September 6, 2018.

Samidi, Raden, and Suharno Suharno. "IMPLEMENTASI NILAI KEADILAN SOSIAL MELALUI PENDIDIKAN PERSPEKTIF TGKH ZAINUDDIN ABDUL MAJID.” Fikri : Jurnal Kajian Agama, Sosial Dan Budaya, December 31, 2018, 374-84. https://doi.org/10.25217/jf.v3i2.314.

Suryawan, Suryawan. "Pola Pendidikan Akidah Di Pesantren Dalam Membentuk Karakter Santri (Studi Kasus Tentang Pendidikan Akidah Di Pondok Pesantren Nurussalam Cintaharja Kujang Cikoneng Ciamis Jawa Barat).” UPI Bandung, 2013.

Thoifah, I'anatut. "Model Pesantren Rakyat Al-Amin Di Sumber Pucung Kabupaten Malang." UIN Maulana Malik Ibrahim, 2014.

Tolib, Abdul. “PENDIDIKAN DI PONDOK PESANTREN MODERN.” Risâlah, Jurnal Pendidikan Dan Studi Islam 2, no. 1 (2015): 60-66.

Wahid, Abdurrahman. Melawan Melalui Lelucon: Kumpulan Kolom Abdurrahman Wahid Di Tempo. Cet. 1. Jakarta: Tempo, 2000.

War'i, Muhammad. Tirakat Sosial: Tasawuf Berparadigma Islam Nusantara. Yogyakarta: UAD Press, 2018.

Yusuf Makmun, TGH. Pengelolaan Pondok Pesantren, September 5, 2018.

Zuhry, Ach Dhofir. Peradaban Sarung: Veni, Vidi, Santri. Jakarta: PT Elex Media Komputindo, 2018 . 
Fikri: Jurnal Kajian Agama, Sosial dan Budaya Muhammad War'i 